CONDITIONING AUDIENCE PATRONAGE USING SUBJECT M ATTERS IN NOLLYWOOD FILMS: THE EXAMPLE OF 30 D AYS IN ATLANTA

\author{
*Silver Abhulimhen OJIESON \\ http://dx.doi.org/10.4314/ejotmas.v5i1-2.21
}

Abstract

Films are subject-based and when producers set out to communicate their viewpoints, some do it flamboyantly while others take the subtle path. Unlike live theatre before it, the possibility of a virile spiral regarding the themes treated in movies can be as much repugnant as they can be fascinating. In this case, the audience are wont to receive without bias some nuances expressed in motion picture for several reasons. Not ably, religious orient ation, gender bias, cultural and racial views, intellectual and philosophical stand, genres as well as mode of reception condition the audience to relate with certain artworks. Without the audience, actors and show promoters would have birth a production meant only for the empty theatre. It is common knowledge that concerns with taste and culture, socio-economic and political considerations affect conception and execution of all audio-visual materials intended for audience consumption. Whether a producer knows it or not, his or her theatrical productions can meet stiff competition from other shows, meaning that the audience is a free for all market. 30 Days in Atlanta, with a favourable record of audience reception and patronage, stands tall as a reference point for manipulating social commentary in its contextual projection of notable issues. Adopting the historical-analytic review approach, the study evaluates the themes inherent in the film as a prerequisite for audience patronage.

Keywords: Themes, Nollywood, 30 Days in Atlanta, Audience patronage, Funding

\title{
Introduction
}

In Peter Brook's famous reference to how theatre works, he illustrates the relationship between men or women in an empty space as observed by other men or women. Here, three things are common: 
the first man/woman (actor/actress), the empty space (location/set/ stage) and the other man or woman who observes (audience) (Brook 3). It is pertinent to note that just like it is not possible to make profit in a marketplace without the consumer coming to buy goods and demand services, the theatre, whether live or mediated, survives on audience patronage. While the concept of patronage simply entails the volume of ticket sales, which serves as admission criteria for the shows exhibited, meaning that, converted to cash, this equals returns on investment, differs from reception.

Reception is the general and specific bias, familiarity and knowledge held by a patron-audience. Previous knowledge of the show, idea about the subjects treated in a screenplay as well as critical perspectives, whether on religious, cultural and political viewpoints, can influence choices of what to watch. So, whereas patronage entails purchases at theatres, reception is the whole gamut of impulses that inform an audience's choice of which film to watch. There are apparently numerous reasons why people patronize theatrical materials, in this study; attention is on the how the patronage is a testament to the kind of reception accorded a film.

\section{Review of Literature}

Edward Gondo asserts that "an audience is any person who chooses to purchase a performance which he desires for a number of reasons (19)." Although the entertainment motive supersedes other reasons why mainstream theatrical productions are created, Ogechi Ekpe posits that entertainment, information, education and therapy (2), in their ranking scale are considered. Despite theatre's inherent ability to attract a certain kind of audience for different shows, it is cormon knowledge that people only watch what they want to see. This is why Barth Oshionebo and Idebi Kayode affirm that "the audience often perceives the theatre as a home of comfort where he/she could relax and catch fun (104)". Hence, it is claimed that "the acceptance or rejection of the play by members of the audience determines the success of any production" and as such "the audience serves as the market for the performance" (Oshionebo and Kayode 105).

Stephen Langley says that "the idea, the place, the actors, the staff, the money and the materials for a theatrical production are brought together and organized for the benefit of an audience (385) ." Thus, the relationship between reality and make believe is at the instance of audience appreciation. This is why Petr Bogatyrev argues that "on stage things that play the part of theatrical signs....acquire special features, qualities and attributes that they do not have in real life (35-36)." However, based on the writer's imagination and life' s 
experiences and observed pattern of societal interactions at large, a lot of dramatic incidents have been captured on celluloid and video for audience consumption.

In Ahmed Yerima' s view, "the audience serves as the public eye that criticizes and enjoys the play at the same time (29)." Arguing further, Yerima holds that "an audience can reject a work of art, and it can also embrace it. These acceptances which may bring financial gains for the production and the comments and newspaper reviews, if they are lucky to get any help to assuage the pains and trouble that have gone into the production (31)" is responsible for the success of most films. The reasons adduced for these, are that the audience wants to partake in the performance by sharing the experience of the playwright and his or her vision. It wants to be educated, and also it wants to take away some useful thoughts and ideas. Other reason why an audience goes to the theatre is because some audience members want to quote the lines, and some want through it to sponsor another play by the playwright (Yerima 32) .

Embedded in the view of Jean Debrix and Ralph Stephenson (21-22) is an opinion re-echoed by Onuora Nwuneli and Alfred Opubor which highlight the fact that "of all the media of mass communication, the motion picture has perhaps the most universal appeal and impact." ...Properly conceived and executed, they assert that "a film can rise above the limitations of language and cultural barriers by the powers of its visual images, its use of music and sound effects, and can succeed in conveying much the same messages to audiences of heterogeneous backgrounds (1)." There is a basic ingredient that glues audience to the screen. This is the plot element known as conflict. Most audience are subject to the world of a film because of its intrigues. This is why Yerima posits that "conflict remains a very import ant part of a play. Without conflict a play would easily fail to hold the attention of the audience. A play depicts a contest in which man's conscious will is employed to achieve a certain goal, which is very hard to reach, and whose realization is actively resisted (33)."

The filmed experience remains the critical bound, a shared experience of suffering and love, culture and nationality, race and kinship as basic ingredients that appeal to the audience. On this ground, the National Film and Video Censors Board's (NFVCB's) The Classifier asserts that "the Nigerian film industry popularly called Nollywood has to its credit the projection of measured Nigerian identity to the world where brands have become a critical currency of global transactions (15)." In the same way, Patrick Ebewo af fims that "Nollywood films are popular in Nigeria because they have indigenous content and address issues relevant to mass audience. Through an 
amalgam of Nigerian narrative techniques (African storylines) and W estern technology, these films document and re-create socio-political and cultural events that occurred within and beyond the country's border (47)." Ebewo further claims that "film approximates reality (52) ." According to Syd Field "film is a visual medium that dramatizes a basic story line... (10)." The audience are only attracted to the film story because it derives pleasure from seeing life re-enacted. The screen image not only transfixes the audience but gives them a food for thought, and this is what occupies their attention for the more than an hour long time in front of the big screen. According Alan Armer "...audiences love to worry. They gratefully accept coincidences that give them more to worry about (15)". Unfortunately, the majority of the films circulating in the Nigerian markets (of Nollywood origin) have drab storylines and bad picture quality and the major reason for this poor state of the Nigerian films has been small budget and the audience preference for better made foreign films. Audience reception of the films has been conditioned in such a way that seeing them is a matter of necessity. II is Armer's submission that screenplays with very bad content will fail to hold substantial audience attention. Hence, Amer opines that "Screenplay progression implies forward movement, that is, new events, new complications, or new revelations that heighten audience interest" (40). Therefore, where these elements are not embedded in the story because of financial constraints, most of them fail woefully at the box office.

According to John MoCall "what mostly distinguishes the Nigerian videos, however, is their popularity. They are watched and talked about by millions of people from every ethnic group and social stratum. I met young people in Lagos who admitted that most of what they knew about village life was gleaned from watching the videos (100)." This is why Jowett and Linton assert that "the content of film can both 'reflect' and 'shape' society, and there is close identification with films st ars (76) ." Garth Jowett and James Linton adumbrate that "the movies thus become a quasi-encyclopaedia in which one finds the visual repository of much of our culture (121)". Growing up, facing the challenges of life and triumphing are basic st ages in everyman' s life. In the screenplay, these basic phases are presented for the audience to relate with. This is why Armer posits that "character growth increases the sense of reality in a screenplay. It also adds to the audience' $s$ sense of fulfilment; all the turmoil has accomplished something (94)". What this amounts to, is that, the audience, knowing that he can relate with a story element and that the film will appeal to him engages in patronising the movies. It is at this point of transaction; between the filmaker and the audience that box office yields its retums. 
Edmund Peters argues that "film with its powerful combination of sound and pictures has the ability of sending down subtle socioeconomic and political realities in entertainment forms. In advanced countries, it has broken out of its narrow entertainment confines into a powerful commercial venture with profound effects on politics and economics (33)." He further claims that a lot of Western countries have taken advantage of the film medium to sell their socio-cultural potentials and canvass for political slots through movies (33). In spite of the place of sub-titles in moviemaking, a tool geared towards reaching more audience, it is notable that while English language films from America and Europe, including other well known languages are used as film language, it does capture our imagination to follow the film story with vivid interest in the content of the movie notwithstanding their use of non-native languages. In this regard, Armer states that "screenplays do not slavishly imitate life; instead, they create an appearance or illusion of life. When directors photograph life situations, the results often are dull and tedious. Screenplays usually are logical and structured; real life is not. Screenplays are economical in dialogue, characters, and scenes; real life is not. Yet screemplays strive to present the essence of life (21)."

In his incisive evaluation of the Nollywood phenomenon vis-a-vis its portrayal of the Lagos City - Scope in movies, Jonathan Haynes observes that "Video film is the primary expressive medium through which Iagos makes itself visible, both to itself and to external audiences (134)." Uchenna Onuzulike asserts that Nollywood film has as its preoccupation a dealing "...with social and moral issues, and the themes addressed include betrayal, infidelity, love and revenge. The most popular genres include love, romance, history, folklore, witchcraft juju and drama (25)." When these thematic preoccupations hold our attention in films, Hyginus Ekwuazi asserts, "...films provide the people the symbols around which to weave their dreams (58)". In Ekwuazi's view, "The cinema, therefore, manipulates the audience into a position from where it all too consciously keeps adjusting its conception of reality, be it within a single movie, or from one movie to another (57)." Frances Harding opines that "... much as the audience are the patrons of the film, most times they are end users who have little or no influence on the content as well as form of the work produced (69)." In the above circumstance, where the filmmaker raises capital for the production, $\mathrm{He} / \mathrm{she}$ also ensures that audience reception is taken into cognizance. Therefore, as a member of the larger society, He knows the tastes/trends and socio-cultural cross-currents well enough to know that to produce anything out of taste might lead to an outright rejection (especially when films do not sell because of their unpopular dictum) . 
Thus it is not out of order to say that audiences will receive whatever idea is presented to them based on the nature of the content, for the medium has inherent ability that makes them appealing to the viewers. Jowett and Iinton posit that "It is more generally agreed that mass media are capable of 'reflecting' society because they are forced by their commercial nature to provide a level of content which will guarantee the widest possible acceptance by the largest possible audience (83)." A critical point in the above submission is the fact that a film is a conmercial product capable of appealing to public views by reflecting via its content audience friendly materials. This view holds for Sussan Langer who says that "cinema is dream in the modes of its presentation; it recreates a virtual present, an order of dire apparition that is the mode of the dream (412)." Yerima explains Langer's postulation above by adumbrating that what happens in a cinema situation as it concems the audience is that "Langer's 'dream mode' of the use of photographic images in television and cinema is further distinguished because both media make use of primary illusion -virtual history- in their own mode (136)."

The audience in front of the Television (TV) or big screen is akin to a dreamer who the dream, that is, the film centres around. This is because in a film, the action moves, places shift, people act, and objects come into view with strange importance. It is this situation in which the audience remains conditioned to the projected image and the relationship of the dreamer is equidistant from all events that place the audio-visual material before the viewer as the centre of the art. Therefore, for most people, the film universe is dream lands that escape to help minimize the reality of struggle in real life. In this regard, Moradewun Adejumo says of the typical Nigerian film that "not only do the films originate under the impetus of local market forces, but they also pander to local tastes in very specific ways (76)."Distilling the market essence of the films from their ethnic values which most film works propagate in keeping with the times, Adejumo believes that the underlying interest in Nollywood movies is consumerism when he states that

"...where Yoruba films appeal to ethnic values and religious films to evangelical conviction, English-language films substitute a blatant creed of consumerism linked to the audience's desire for narratives of social mobility. Advertising the film and advertising in the film has been most aggressive with English-language film (85)." 
It is this commoditization of the Nigerian film industry that gives it a status of a business venture, not a class room subject, although it is subject to the whims and caprices of the scholastic effusions of an eccentric academia. The commercial success of these films is directly influenced by the audience patronage. The place of the audience is so significant that without it the dream of a blockbuster would be in vain. In spite of the ethnic diversity Nigeria is ermeshed in, it has been able to hamess its local talents for local viewership. Thus, in places like Kano, there is predominantly Hausa/Fulani films, in the westem region, Yoruba films compete favourably with English language Nigerian films and imported brands. Aside Ibo language films, minor ethnic groups such as Efik/Ibibio, Benin, and dialect films are commonplace. All of these have a large enough audience to sustain the business of production and exhibition of film works thereby guaranteeing proportionate returns in investment. The significant milestone, given the recent box office returns on some cinema placement of Nollywood movies have underscored a trend in the way genres, actors, picture quality and funding influence the total makeup of a production.

\section{Days in Atlanta:A Synoptic Analysis}

Richard is an IT consult ant for Lekki Gardens, Lagos. At one of the company' s customers' appreciation party, he brings Akpos, his cousin along. Fortunately, Akpos picks a raf fle ticket for a trip for two to holiday in the United States for thirty days. This immediately becomes a news item, both on Radio and far away Warri where Akpos come from. Richard, who is to accompany Akpos receives a surprise visit from Ese, his estranged lover. The circumst ance of their breakup, following Ese' s rejection has left Richard emotionally feeble. However, when Ese shows up claiming to love him, he immediately rebuffs her. Their preparations to travel to Atlanta, the designated city Lekki Gardens chose is accompanied with fanfare as Akpos and Richard begin to shop for designers' wears and other items. On their way to Atlanta, Richard eats aboard with gusto while Akpos, though hungry watches with jealousy. When the hostess informs him that the food is not for sale, Richard knowing all along that Akpos was a novice had deliberately deprived him the knowledge of this service. Akpos is so angry he takes it out on the left over salad. When they land in Atlanta, from the airport they are driven down to the booked apartment and shown around by a male attendant. Wowed by the luxurious apartment, Akpos and Richard allowed their excitement, innocently to overcome them by hugging and playfully fighting over the key to the master 
bedroom. This sends a wrong signal to the male attendant mistaking them for a gay couple.

Akpos and Richard, after settling in dress up and step out to explore the city. Their steps are fleeting and they walk down the est ate as if they were the owners of the properties. In the course of the walk, they notice a woman struggling with her daughter who would not move. Akpos intervenes, thinking he was helping the mother but to his chagrin he incurs the wrath of the woman who apparently detests spanking her child. Akpos and Richard's first experience is not a palat able one. When they visited a restaurant and Akpos requests for a beer, the attendant demanded for identification. This greatly infuriates Akpos who begins to use swear words because he was referred to as a minor. It took Richard's intervention to avoid any scene. Successive scenes are full of Akpos' reaction about the culture of their host. A couple kissing at a park is harassed by Akpos as being indecent, asking if they have no room. This is followed by his incursion into a dance rehearsal where he is out to teach the Americans how to dance and hands the DJ a mix tape. Akpos danced so well he is carried shoulder high, at the climax he names Richard as his manager but Richard races out of the venue scared what legal implication this might have on him. When Richard and Akpors, in the company of a Nigerian from W arri visit a cafe, they sight an extremely beautiful woman, Kimberly who Richard fancies.

Akpos and Richard pay Uncle Wilson a visit. To their greatest disappointment, it turns out that Uncle Wilson is the cook and baby sitter. In spite of the respect and reverence Akpos had for Uncle Wilson, he could not hide his resentment. He hurries Richard away and they both decry their uncle's predicament. This is an Uncle that was so strict he thought them their first lessons of life back in Wari. They are so helpless they cannot understand why such a feared uncle can bring himself so low as to be kicked about by his American wife. From Uncle Wilson's place, the scene transits to Metro Fusion, venue of the conference being attended by Dr Erikefe. Kimberly and her father-Mr Odiye are taken in by Akpos' remarks about the use of tear gas by law enforcement officers during riots as air pollution. His humorous and hilarious nature sails him through the interaction with Kimberly . Richard, who does not participate in the Akpos and Kimberly chat, is totally blown away by her beauty he fidgets against Akpos' dismay. Taken in by his comic disposition, Kimberly requests if Akpos would love to come do stand up comedy at the restaurant during the weekends and he jumps at it. Over the successive weeks, Akpos makes jokes entertaining customers at Metro Fusion until one night when they were returning home without Richard's wallet. When Richard made it known 
to Akpos that he was not with his wallet, they immediately began to confer on how to alight and run away before the taxi driver can reach for them. At this point the taxi grinds to a halt and a pistol points to their forehead. Unknown to them, the American taxi driver underst ands Pidgin English and knew what they were planning. He throws them into the cold without trousers and shirt, left for their boxer shorts they would have both been naked.

In a couple of minutes, Mr Odiye and Kimberly, who Richard called showed up and took them home. Akpos and Richard are given a pair of track suits and hot cups of coffee while her father narrate how he came to be in America following the Nigerian Government's attempt to kill Kimberly's mother as a CIA agent following the toppling of the Government in 1993. Moments later Clara, an immigration lawyer friend of Kimberly's father shows up and makes their company. The opportunity gives Akpos inkling about Clara's personality and when they made to leave, Akpos demands to know if Clara was married. From this moment Akpos goes all out to win Clara's heart and the romance between Richard and Kimberly brews well. When Richard had a chat with his mother, she tells him of how well Ese has been helping her with her roast fish business. He makes it clear to the mother that there was nothing between Ese and him and so she should send her away. The following day when Richard was inside an arts shop framing a picture frame of Kimberly, Akpos who is supposed to wait outside decides to gamble across the road. When Richard comes down he hoodwinks him into meeting Kimberly at home that he will be fine. Given the urgent urge to get home before Kimberly, Richard leaves Akpos to take care of himself Unfortunately, Ese was with Richard's mother and as soon as Richard's mother saw that Richard was not there, she stepped out and left Ese who manoeuvres everything telling Kimberly she is married to Richard. She warns Kimberly to avoid his deception. This breaks her heart much so that Kimberly, fill of tears leaves before Richard arrives.

A police patrol vehicle arrests Akpos. He is taken to a remand facility where he calls Richard and begs him to call Clara. Moments later, Clara shows up and tries to save Akpos but he would not keep quiet, unfamiliar with the way the law in America operates. Accused of having so much money on him, thinking that by avoiding any attempt by the officers to make him say he was gambling he would be helping his case, Akpos says he worked for his money. This violates his terms of admission into the United States as a visitor. Clara, st anding in for him wriggles Akpos out of going to jail. He would have to donate what he earned at Metro Fusion to charity to redeem himself. Richard, already annoyed with how Ese has messed up his relationship with 
Kimberly, huts. Every attempt he makes to explain himself to Kimberly turns out fruitless. Upon Akpos' release, Clara takes advantage of Richard' s condition to invite Akpos to spend time with her, part of which she says is to keep an eye on him lest he misbehaves as she promised the judge she will keep an eye on him. At Clara's place, Akpos becomes romantic and conquers Clara. He is so excited he boasts about it on phone, claiming that he was going to get a green card out of Clara. Unknown to him, Clara who is within earshot heard all his ranting and decides to throw him out of the house. Akpos, begging her to understand it is just a mere talk is refused audience by Clara who pushes him out.

Mr. Odiye steps in on one of Richard's reconciliatory trips and stemly warns him never to bother his daughter. In his manner of reference, he reminds Richard of how untrustworthy Nigerians are by informing him about how credit cards are scrutinized and dollar bills are scanned to ascertain their authenticity once in the hands of a Nigerian. This breaks Richard's heart owing to Ese's act about their purported marriage. Akpos and Kimberly are at a garden and in a romantic pose when Akpos, for the first time speaks queens English and expresses his feelings towards Kimberly and demands a kiss. Kimberly obliges Akpos of the kiss and he keeps eating his lips until Richard taps him from his slumber. When Akpos wakes, he remarks that he knew it could not have been true that he spoke fluent English, this confuses Richard who he refuses to inform about whom he was kissing. Richard Skypes with Ese and warns her to steer clear his path. With Richard in lead, Akpos donates the money to charity grudgingly so as to get court clearance. At the ainport, Akpos and Richard are surprised by Kimberly and Clara who showed up with their tidkets to Lagos. This scene climax the 30 Days in Atlant a sojourn embarked upon by Akpos and Richard, courtesy of Lekki Gardens.

\section{Themes Explored in 30 Days in Atlanta}

Tourism: The central idea in this film is the trip embarked on by Richard and Akpos, courtesy of Lekki Gardens. In the movie, emphasis is placed on the sheer culpability of Akpos, generally considered a village brought up and one whose limited exposure has impacted negatively on his rapport with people. For this purpose, Akpos really needs to get his act together. Richard, who pretends to be cool with Akpos feels disgraced every now and again. In the long run, the trip sumarily gives Akpos needed the leverage to make concrete his numerous boast ful insinuations. What is critical in the Atlant a trip is the fact that Lekki Gardens shows us the place that Richard and Akpos are lodged, using this link as juxtaposition on the laudable prospects of patronage accruable to real estate ventures of Lekki Gardens. 
Social Commentary: The movie takes advantage of the comic genre to conment on socio-cultural occurrences. For inst ance, Akpos decries his Uncle Wilson' s inability to take charge as the head of his family. His wife controls him as she made him a 'woman wrapper'; he cooks, changes the baby's diapers and mops while the wife does nothing meaningful but paint her nails. Richard, who slightly underst ands Akpos' uncle' s plight, pleads with Akpos to stop his derision. Survival, instead of claiming head, turns out key, among other things. The 'green card syndrome', which the uncle obviously needs cows him and gives Akpos a decrepit notion of his Uncle. The lottery won by Akpos and Richard is a way of looking at the 'awoof' syndrome that most Nigerians dream daily of, and for this reason, some are waiting on God for manna to rain. On their first ating in Atlanta, the duo encounters a girl crying while her mom begs her. On seeing this, Akpos is of fended and lambasts the girl's mom for not flogging her. If it were in Nigeria, the girl would have had it tough. In addition, the Abdul Mutallab terror scare is reenacted as Uti Nwachukwu portrays this character, again Akpos draws their attention to this phenomenal Boko Haram protégé.

W arri myth: The name of Akpos it self is a generated acronym for a comically endowed Niger Delta boy who takes swipe at anything that is capable of mirth. It is assumed that the average Warri brought up is a comic actor.Akpos' 'misbehaviour' is forgivable because there is an imaginary standing order for his ignorance to go unpunished. At the venue of the raffle, of all the people in the gathering, it is Akpos, for crying out loud who wins the raffle. To validate his claim, he shoutshe is my couples! So as to lend credence to the trip's intent for two. What a coincidence? Well, it is a film and a comic one at that; so the contrivance is permissible. In USA, Akpos meets Clara, an immigration lawyer he really likes. The average Warri boy is a warrior, fears no one and bold as the lion, is a king, no matter the jungle. Clara chose to consider Akpos not because she is comfortable with his age but because he is really forward. Akpos' favourite phrase-your father! Further establishes his Warri origin. Words such as 'Kponkpi' and the plethora of slang he uses are meant to reiterate his background.

Infrastructure: The movie makes ample references to the level of infrastructural development between Nigeria and America, in terms of the level of manpower development. Richard, the enlightened of the duo, at every opportunity never stops to remind Akpos that things work in America unlike in Nigeria. For example, when they rented a car , Akpos' thinking is simply to ship the car out of the United States. One notable statement made in the movie is the provision of leisure infrastructure, especially outdoor facilities for relaxation, sports and 
picnics. Real estate, modern architectural designs and the housing trends were brought to bear on the level of Lagos' metropolitan exploits to be at par with the home business network worldwide. Elite residential quarters in Nigeria, especially in the Government Reserved Areas (GRA) which have been taken over by private estates accounts for a large chunk of the urban housing provider in post Abacha regime. This new housing culture, upwardly mobile and convertible, exemplify the tastes of the nouveau riche.

Greener pastures: Generally, in the Nigerian context, anyone who is opportune to travel out of the country is considered fortunate. His or her fortune, once he or she leaves the shores of the country is generally believed to have changed for the better. This misconceived notion of wealth does not allow for any excuses especially when it is known that some rich people in the community have travelled overseas and returned with more wealth. Seeking for greener pastures abroad has never been equated with the same amount of time and energy expended at work, but on the merit of economic differentials. This urge to easily travel by Nigerians is preconditioned on the exchange rate of a USA dollar or British pound to the Nigerian naira. This conversion power, of a relatively small sum translating into a huge amount in Nigerian parlance is the craze which drives many people to seek greener pastures. So, Okeimute is an ordinary fuel attendant in Atlanta, Georgia. Back home, his known profile is of someone who works in an oil and gas company. This is equivalent to saying he works with NNPC, Shell BP or Chevron and the likes if he were home. A cursory look at Richard, it becomes apparent that his desperate advances to have Kimberly may not be wholly due to love and companionship but as his escape ticket from poverty. Richard is obviously handsome and employed, these are not enough. His mother still struggles and things are not all good back home, the major reason he is sworn to reject Ese and go for Kimberly, daughter of a wealthy restaurateur makes a very good escape route from poverty forever as a son-in-law.

\section{Conclusion}

30 Days in Atlanta out sold Head Gone. Matter of fact people don't even remember Head Gone because their release dates was auspicious for the former and detriment al to the latter. What has release dates have to do with box office performance if not for choices? Remember opportunity cost in secondary school economics? Well, in spite of the similarity in genres and despite the huge presence of notable faces, the latter failed to make box office impressions. This simply reiterates the idea that the audience is the epicentre of theatrical 
works. Their choice translates into convertible retums for the producer. Thus, Ayo Makun's huge box of fice receipt was not determined by some sort of technical or artistic landmark contained in the production, but arguably the stiff competition regarding subject matters. This takes us back to the issue of genres and the comic genre plays out against itself here. On interacting with some members of the production audience, a lot of them opine that there were many instances where Osuofia in London was replicated in 30 Days in Atlanta. In particular, Akpos' reprimand of a kissing couple is one case in point. However, that the huge patronage accorded 30 Days in Atlanta was massive indicates how intrigued by the screemplay audiences were. Well, several factors, not so straight lined, account for this reception which could have been influenced by the fact that it is common knowledge that a people are naturally predisposed to laughter no matter how canned it turns out. Funny and witty expressions with especially actions without repressive consequences have an aloft place of its own. In this state, a man or woman can attempt the obvious and get away unhurt. Here, the dramatic genre of comic bawdry acts is permissive; ludicrous actions which instigate laughter come to the fore.

In the comic dramatic genre, the law of the natural state of things is upturned for the unheard and untold to have its course. It is under this guise that Akpos thrived in 30 Days in Atlanta. There was massive TV and Radio commercials, News Paper reviews and social media created publicities announcing the notorious deeds of Akpos. Having proclaimed the coming of such a huge budget flick, especially "the making" which displayed the Americanized cast and crew, as if anything 'Oyinbo' is perfect, the home based audience was naturally predisposed to having to be the first to see this Hollywood-meets-Nollywood flick. The sheer depth of the publicity and the boisterous slant accorded the exploit s of Akpos was akin to a feat no Nollywood production has ever dared to achieve. People have been overwhelmed by the Akpos' shenanigans, this is critical upon evaluation of his 'Warri-Brought-Up' characteristics. Due to the large number of stand-up comedy acts from the Niger-Delta region, with seven out of ten jokes always making reference to Warri, it is assumed that any Akpos is a natural when it comes to provoking mirth.

A cursory look at Mr. Odiye's fant abulous tales of his escape from Nigeria, which in most circles will be, to be candid, long story, only fit for the gods; incite some hissing. But his daughter's relationship with Richard, their romance and her father's imposing personality, which at the centre seems to threaten their affairs, is not new in Nollywood and film culture where gold diggers hustle for the rich family's wealth. The audience who see Richard's quest as a passport out of 
the land of wretchedness did not hold anything against him. His hustle, like Akpos' paid eventually as Akpos and Clara, of age difference and green card syndrome, the latter also manifesting in Uncle Wilson's marriage to his American wife, wherewith he has become a woman wrapper is also not new in Nollywood. Ye, 30 Days in Atlant a is judged Nollywood's highest selling movie of all time, a major reason, which is arguable, is simply the ease with which its subject matters were treated with straining the topic. The intricate interplay of stand-up comedy and the notorious influence it has had on comic elements in Nigerian films cannot be overemphasised. So, Ayo Makun, aka, AY stars in 30 Days in Atlanta as Akpos-all hell is let loose at the Box of fice. I am partialarly taken by the interpretation given the Akpos character by AY's language; heavily obscene, lewd, concocted and in particular, his body alignment as if he was hit by a truck from behind. The muffled and raucous laughter I heard at the cinemas were 90\% triggered by Akpos' language. His speech in partialar, which most times were not directed in a dialogue but were social commentary in most cases uplifted the screenplay' s profile. Your father! No, your dad!

\section{Works Cited}

Adejumo, Moradewun. "English and the Audience of an African Popular Culture: The Case of Nigerian Video Film." Cultural Critique 50 (2002): 74-103.

Amer, Alan A. Writing the Screenplay . Califomia: Wadsworth, 1993. Bogatyrev, Petr. "Semiotics in the Folk Theatre." Matejka and Titunik, 1976.

Brook, Peter. The Empty Space. New York: Atheneum, 1968. Debrix, Jean R. and Stephenson, Ralph. The Cinema as Art. Baltimore: Penguin, 1969.

Ebewo, Patrick T. "The Emerging Film Industry in Nigeria: Challenges and Prospects." Journal of Film and Video 59.3 (2007) :4657.

Ekpe, Ogechi. Introduction to Drama. Lagos: God's Time Press, 2008. Ekwuazi, Hyginus. Film in Nigeria. Ibadan: Moonlight, 1987. Field, Syd. The Definitive Guide to Screenwriting. London: Ebury Press, 2003.

Gondo, Edward D. Marketing the Nigerian Theatre. Makurdi: St Kalemba, 2002.

Harding, Frances. "Africa and the Moving Image: Television, Film and Video" Journal of African Cultural Studies 16.1(2003):6984.

Haynes, Jonathan. Nigerian Video Films . Chio University; Athens, 2000. 
Langer, Sussan. Feeling and Form. London: Routledge and Kegan Paul, 1959.

Langley, Stephen. Theatre Management in America: Principle and Practice New York: Drama Book, 1980.

Joweth, Garth and Linton, James. Movies as Mass Communication. $2^{\text {nd }}$ ed. London: Sage, 1989.

MoCall, C. John. "Nollywood Confidential." Transition 95 (2004):98109.

National Film and Video Censors Board (NFVCB). The Classifier 3.1. Lagos: NEVCB, 2010.

Onuzulike, Uchenna. "Nollywood: The Birth of Nollywood Movie Industry" Black Camera 22.1 (2007): 25-26.

Opubor, Alfred and Nwuneli, Onuora. The Development and Growth of the film industry in Nigeria. Lagos: NCAC, 1979.

Oshionebo, Barth and Kayode O. Idebi. The Principles and Practice of Theatre Management in Nigeria. Ibadan: Impact, 2009.

Peters, Eomund. "Film as an Instrument of Diplomacy" Film and Video. Jos: NFC, 1993.

Yerima, Ahmed. Fragmented Thoughts and Specifics: Essays in Dramatic Literature. Lagos: Bookplus, 2003.

\section{Filmography}

Robert, Peters (Director). 30 Days in Atlanta. Lagos: CWE, 2014. DVD Dare, Fasasi (Director). Head Gone. Lagos: Naija Ninja, 2014. DVD 